Sonic Scope: New Approaches to Audiovisual Culture • Issue One

\title{
The Essence of Femininity: The Subversive Potential of the Music Video Aesthetic in Perfume Advertisement
}

Emma Payne

Published on: Oct 06, 2020

DOI: $10.21428 / 66 f 840 a 4.0 c b d f 606$

License: Creative Commons Attribution 4.0 International License (CC-BY 4.0). 


\section{ABSTRACT}

The Essence of Femininity: The Subversive Potential of the Music Video Aesthetic in Perfume Advertisement Emma Payne, Cardiff University School of

Music

In order to overcome the intangibility of aroma, perfume adverts have typically relied on fantasy narratives, utilising the sensuality of sound and music to evoke intimacy and emotion. Associations between scent, sex and romance have led to objectification and stereotyping of women, particularly celebrities - treating them as the products on sale. However, I will argue that some adverts have begun to challenge these representations by repurposing the artistic freedom, creative technology and audiovisual relations characteristic of music video. The aesthetics of music video have enabled a new model for perfume advertising in a way which has yet to be explored. To do so, I will discuss audiovisual tropes in perfume commercials from Chanel, Revlon and Yves Saint Laurent and in music videos from artists such as Lady Gaga and Sia. Drawing upon these examples, I will reveal the ways in which Kenzo's 2016 "Kenzo World" advert creates a rebellious new style of perfume advertisement. In turn, I will address the potential for further crossfertilisation across media, whereby Kenzo's innovations feed back into the music video genre and create new implications for women on screen.

\section{Introduction}

When screen siren Marilyn Monroe famously claimed to wear nothing but Chanel No. 5 to bed, she reaffirmed a long-standing relationship between perfume, femininity, and sexuality; a connection which fragrance commercials have often capitalised on through gender stereotyping and the promise of sexual encounters as a 'reward' for purchasing the product. 1 This method relies on presenting the woman on screen as a sexual object using overt language and intimate or erotic imagery, evident in recent adverts from Dior, Jimmy Choo, and Paco Rabanne. ${ }^{2}$ However, I argue that adverts can subvert this restrictive approach using the unique aesthetics of music video, producing a rebellious new model exemplified by Kenzo's 2016 "Kenzo World” advert. To explore this notion, I will discuss the audiovisual rendering of women in more archetypal perfume commercials and in music videos from artists such as Lady Gaga and Sia. Drawing upon these examples, I will illuminate Kenzo's disruptive approach and trace further cross-fertilisation between these media forms - specifically, the intersection of fame, branding and femininity in Taylor Swift's "Delicate" music video. 
In March 2018, a European Parliament study found that media portrayals of women "too often conform to tired clichés," and centre on "stereotypical (home- and family-focused), sexualised, or auxiliary roles." $\underline{3}$ Central to concerns about such narrow representations is the concept of gender socialization, whereby "the media provide acceptable notions [...] of masculinity and femininity" which are then "observed, reflected upon, and imitated" by viewers, thus perpetuating these limiting gender stereotypes in everyday life. $\underline{4}$ These "acceptable" forms of masculinity and femininity stem from a binary categorisation of sex based on a "narrow range of biological differences," excluding those who do not fit the binary and therefore significantly restricting the possible range of gender expressions. $\underline{5}$ The resultant codes for the normative expression of 'masculine' and 'feminine,' which extend to appearance, voice, behaviour, and sexuality, thus come to be perceived as 'natural' due to their ostensible connection to biological sex - a perception which of course has been widely criticised throughout gender studies. $\underline{6}$

Perfume advertisements are regularly based on such binary gender categorisations as the products themselves tend to be marketed explicitly to either men or women, which is often the case with cosmetics and clothing advertisements. Across brands and industries, advertisers commonly sell experiences, aspirations and emotions which are then associated with the product - a technique epitomised by perfume advertisements, especially due to the intangible nature of scents. In perfume adverts, these experiences revolve around associations between perfume, sex and romance, and are constructed through a range of filmmaking techniques: evocative colour palettes, seductive voiceovers, framing and editing of shots. Music and sound play a central role in creating a sensuality akin to smelling perfume. Like scents, they can arouse bodily sensations, emotions, memories or associations with action or romance films. But unlike aromas, they can be projected onto a viewer through video advertisements.

Commonly, a heteronormative romantic or sexual relationship forms the basis of the narrative within these adverts, offering a seductive fantasy which can supposedly be recreated with the purchase of the perfume. In particular, women are used to "sell products to both women and men on the basis of their sexual appeal to men," with male consumers viewing the female in the advert as a "bonus that comes with the product."- This format is often heightened through the use of female celebrities, who act as both the fantasy and the 'reward' for buying the perfume. Recent examples include model Emily Ratajkowski for Paco Rabanne (2018), actress Jennifer Lawrence for Dior (2018), and Marilyn Monroe as archive footage for Chanel (2012). This type of celebrity figure, Steven Shaviro argues, works as an ideal commodity: they are unattainable icons who we can never know intimately, yet we are constantly drawn in by the suggestion that we might. $\underline{8}$ Their personas are fixed, recognisable points on which "powerful feelings converge," yet they are equally fluid, unreal and elusive. $\stackrel{9}{ }$ These paradoxes are present in adverts that allude to sensuality and intimacy through 
aesthetic choices, music and sound, but feature a celebrity who will never be accessible in reality even through the purchase of the perfume.

As a result, women in perfume advertising tend to be objectified, reduced to their physical characteristics, and shown to conform to established gender norms. Additionally, they usually represent an extremely limited segment of the female experience: young, cis-gendered, white and able-bodied women are the most commonly visible portrayals. $\underline{10}$ The ways in which these representations might perpetuate an 'ideal' femininity, and how this could influence the self-esteem and purchasing behaviour of female consumers, would need to be tested through empirical audience research. $\underline{11}$ Here, I will lay the foundations of such research at a textual level, beginning with more archetypal perfume advertisements from Chanel, Revlon and Yves Saint Laurent. By drawing attention to the under-examined role of music and sound in perfume advertising, textual analysis can offer novel insights into how these representations reaffirm or challenge stereotypical and clichéd notions of femininity. Further to this, by looking in detail at how female identities are constructed through music, sound and image across a variety of examples, I can trace cross-fertilisation between advertisements and music video as part of a broader web of intersecting media genres - culminating in my discussion of Taylor Swift's "Delicate" video.

\section{Seductive Beauty and the Illusion of Intimacy: Archetypes in Perfume Advertising}

An early example of how perfume advertising creates fantasy narratives is the series of Chanel No. 5 commercials starring actress and model Catherine Deneuve, which were broadcast during the 1970s. Throughout the adverts, Deneuve's star status and film persona are capitalised on by allowing the viewer to believe they are experiencing the 'real' woman behind the films. Deneuve is illuminated against a black background, describing her relationships with men and Chanel in a soft voice without any musical accompaniment. The exclusive sonic focus on her hushed voice encourages the viewer to listen closely to her and fixate on her lips, while her fixed gaze, aimed directly at the camera, creates the impression of a personal conversation.

In "Whispered" (1973), she discusses "private moments together" with an unnamed man who buys her Chanel No. 5, the seductive content of her speech enhanced by the soft focus and intimate close-up of her face. $\underline{12}$ 


\section{Visit the web version of this article to view interactive content.}

Video 1. Chanel, “Whispered - CHANEL N 5," September 26, 2012, accessed April 19, 2020, https://www.youtube.com/watch? $\underline{v=T G V N G O M X E 2 C .}$

The positioning of her arm and hand in front of her face suggests vulnerability and shyness as she describes feeling "awkward" about being "so lost in feelings," thereby playing to the stereotype of a delicate female in need of a confident, protective male presence (see Figure 1).

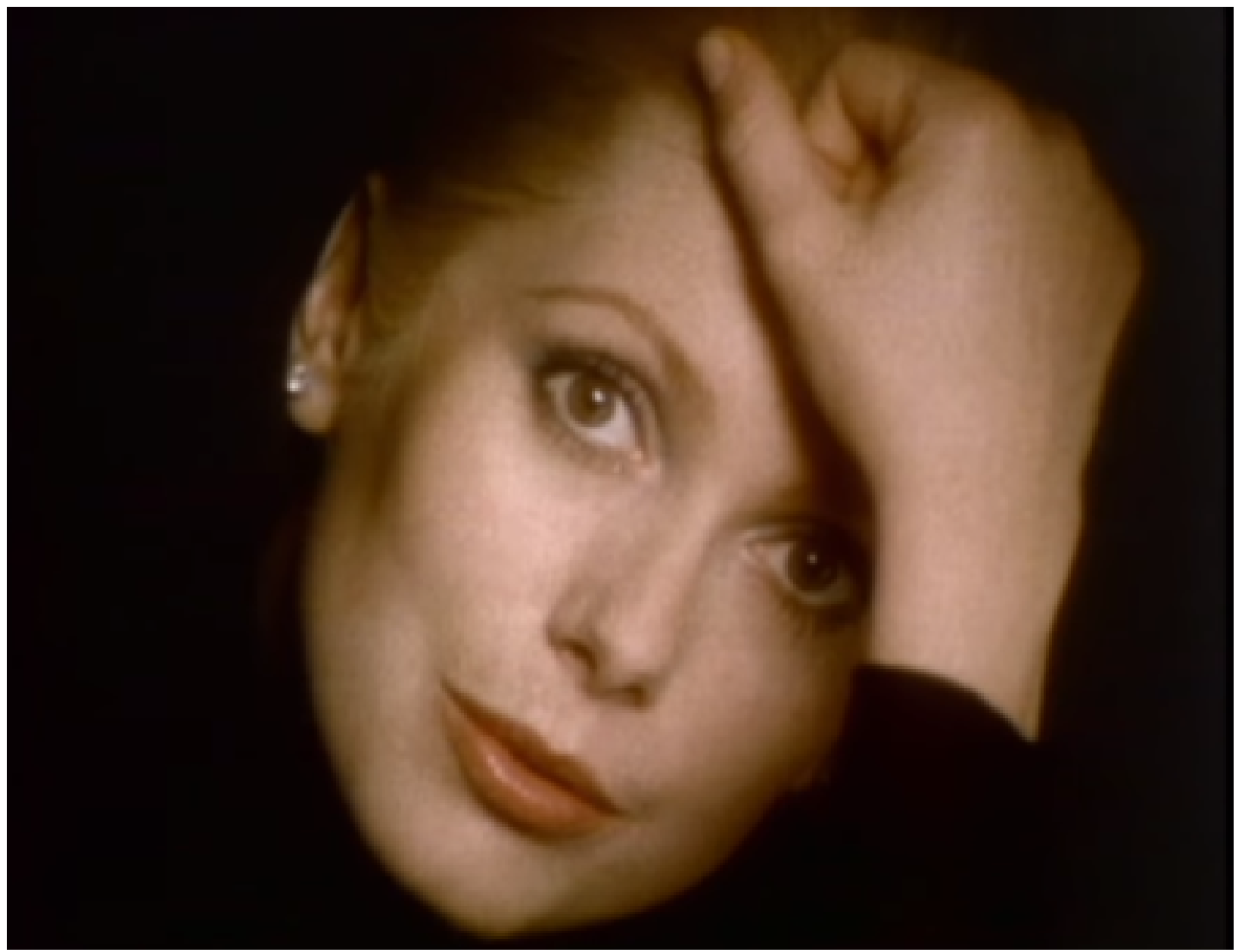

Figure 1. Catherine Deneuve's disembodied face and hand in Chanel No. 5's "Whispered"; screenshot taken from Chanel.

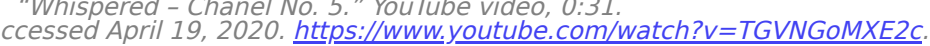

The sound of her French accent portrays both her and the perfume as exotic, rare and therefore desirable commodities. Furthermore, fetishization of eyes and lips and the stillness of this advert mirror director Helmut Newton's erotic fashion photography, which lends itself to this commodification. Although her lips move, Deneuve's face is static, as if captured in photograph, enhancing the viewer's perception that both she and the Chanel perfume are objects for sale. $\underline{13}$ 
Deneuve's intense eye contact throughout the majority of this clip is also significant in terms of Laura Mulvey's theory of the "male gaze." $\underline{14}$ The Chanel advert consciously capitalises on the objectifying presence of the male gaze, seducing the male viewer into believing that he is seeing the tangible, 'real' Deneuve - albeit one who is just as calculatedly stylised as her cinematic counterpart. Like Madonna in her "Justify My Love" music video, as argued in Sheila Whiteley's analysis, Deneuve returns the gaze and knows she is being looked at, thereby "simultaneously submitting to that inspection and controlling it." $\underline{15}$ This control is exercised at the end of the clip, where Deneuve breaks her previously unwavering eye contact to glance at a Chanel No. 5 bottle (0:29). This technique directs the sexual fantasy projected onto her towards the product, with the double entendre "you don't have to ask, he knows what you want" confirming the connection between the two and encouraging a purchase.

The lack of music, camera movement or background scenery create a sense of peeling back the cinematic layers and effects through which we usually see Deneuve. This stripped-back aesthetic allows the viewer to feel as though they are sharing a 'private moment' with her - a particularly tempting proposition, given Deneuve's star status and history of erotic portrayals in films such as Belle de Jour (1967). As a result, the advert uses Deneuve's fame and unattainability to suggest this kind of fantasy experience might occur following the purchase of the perfume. Reinforcing stereotypical gender roles and manipulating the erotic cinematic/vulnerable 'real' personas of a movie star therefore has commercial benefits in terms of this advert, and many others throughout the industry.

The practice of exploiting women in this way also extends to perfume adverts aimed predominantly at female consumers. Revlon's 1979 "Charlie" fragrance advert uses a jingle combined with images of charismatic model Shelley Hack to portray the 'perfect' modern woman; an ideal in which female buyers are encouraged towards wearing the "Charlie" scent. $\underline{16}$

\section{Visit the web version of this article to view interactive content.}

Video 2. Darian Glover. "Revlon Charlie Commercial (April 2, 1979)," May 14, 2009, accessed April 26, 2020, https://www.youtube.com/watch?v=t1WX9znN7CE.

A common 'hard-sell' musical strategy most common between the 1930s and 1970s, the jingle was a popular method of directly "singing the praises" of a product using a catchy tune based on mainstream music of the era. .17 The "Charlie" jingle, performed by jazz singer Mel Tormé, repeats the name of the product and describes it as "kinda young, kinda now / kinda free, kinda wow," encapsulating attributes of the woman on screen as well as the perfume itself. At the same time, the viewer sees Hack wearing a trouser suit - still regarded unusual attire for a woman in 1979 - and confidently striding through a bar, exuding a sense of the 'modern woman' and rejecting the typically 'feminine' traits such as vulnerability or dependency which are communicated by Deneuve's Chanel No. 5 persona. 
However, central to the advert's narrative is Hack 'wowing' the men she encounters, arguably in reinforcement of the opposite-sex-as-'reward' model, as discussed in relation to Chanel's advert. "The world belongs to Charlie," a male voice declares at the end of the clip, but her success is largely due to her conventional - white, thin, blonde - beauty and ability to entice men. $\underline{18}$ By using a male singer and male voiceover, the potentially progressive elements of the advert are further undermined by the advert's failure to give Charlie a female voice. This ties in with a perception in advertising that the male voice "is more authoritative and convincing," even with respect to products targeted at women. $\underline{19}$ Similar tension between attempted innovation and gender stereotyping appear in Yves Saint Laurent's “Rive Gauche” fragrance advert from the same year. $\underline{20}$

\section{Visit the web version of this article to view interactive content.}

Video 3. Robatsea2009, "Rive Gauche Perfume sexy 1979 TV commercial," August 14, 2012, accessed April 29, 2020, https://www.youtube.com/watch?v=-k-SMhod7Jy.

Conflict arises between the lyrics of the jingle, describing an "independent woman" who is "having too much fun to marry," and the visual content of the advert. The images focus on her face (0:03), feet (0:04), legs (0:05) and neck (0:16), suggesting that the 'fun' she experiences is sexual independence; arguably reinforced by the narrative of driving a car, thereby taking control and actively pursuing her own 'sex drive.' However, under the guise of female sexual liberation, these images ultimately reduce the 'independent woman' to her physical attributes in a similar way to the Chanel and Revlon adverts (see Figures 2-3). 


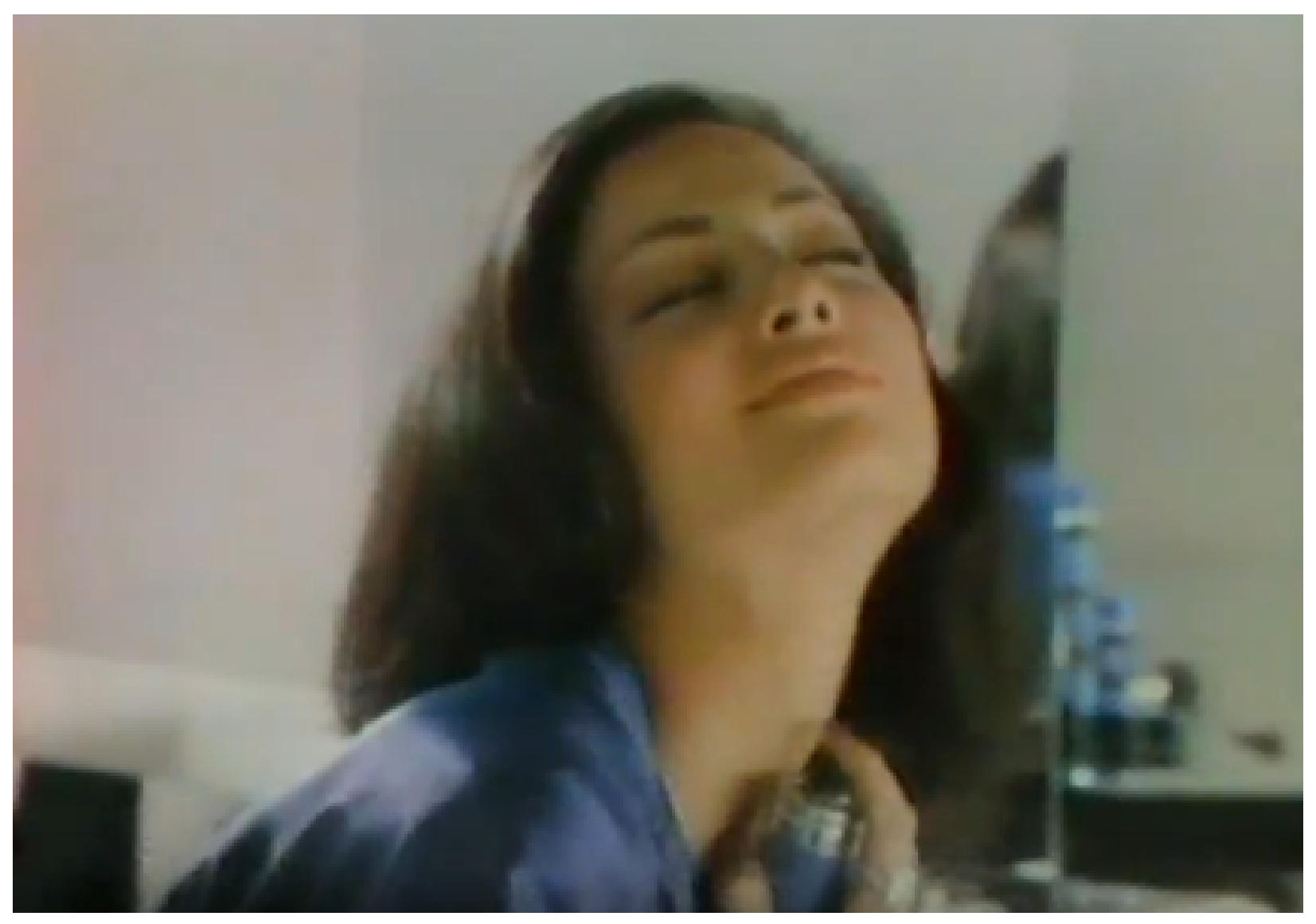




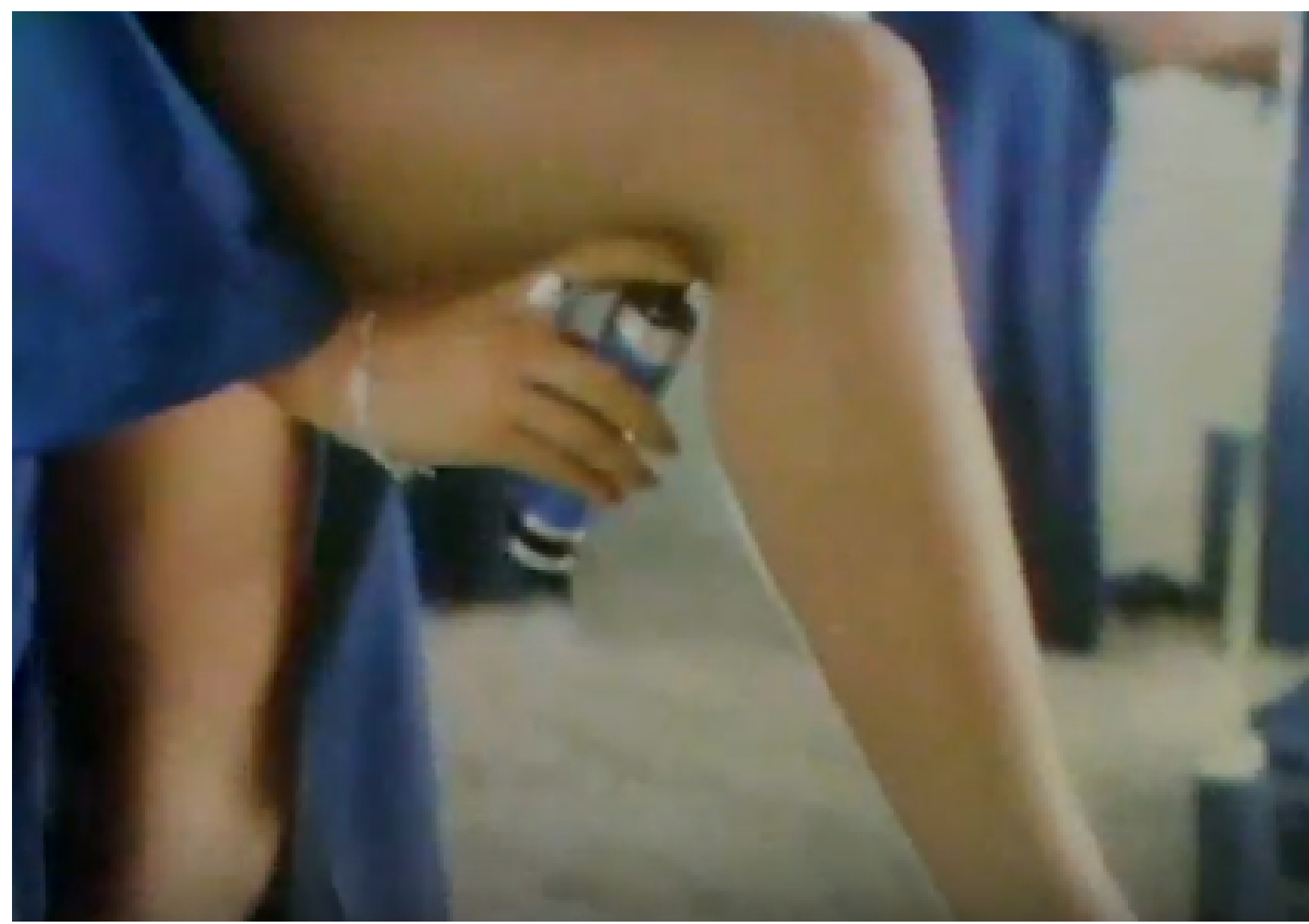

Figures 2-3. Objectifying imagery in Yves Saint Laurent's "Rive Gauche" (1979); screenshots taken from "Rive Gauche Perfume sexy 1979 TV commercial." YouTube video, 0:30

https://Www. youtube.com/watch?v=-k-SMhod7Jy

Male and female voices declare this woman is "nothing like the past," but the entire clip reinforces the archaic method of objectifying women to sell perfume, even to female consumers.

\section{A Rebellious Aesthetic: Music Video}

Whereas these perfume commercials rely on women's sexual appeal, conveyed via explicit romance narratives, objectifying imagery, jingles or voiceovers, the music video aesthetic provides a radically different audiovisual model with the potential to challenge these outdated, damaging tropes. When MTV emerged in 1981, it launched a new type of media featuring a "fast-paced visual language," emphasis on aesthetic appeal and an innovative approach to audiovisual relationships. $\underline{21}$ Mathias Bonde Korsgaard outlines the following key features of the genre:

(1) brevity: (2) a combination of visuals and music; (3) pop and rock music as the sound track; (4) the song preceding the visuals; (5) [...] a dual scope, both commercial and entertaining [...] (6) no 
incisions are made in the song's structure; its length determines the video's length; and (7) the image illustrates features of the song in order to sell it. $\underline{22}$

The seamless combination of commerce and entertainment and the notion of music as a determining force in the production, rather than just accompaniment to visuals, had a lasting impact on product advertising. As Carol Vernallis has argued, directors of music video were free to break the rules inherited from traditional film; as long as the visuals drew attention to the music and the performer, which were the 'products' to be sold, videos could be abstract or narrative, editing could be noticeable, disjunctive, and rhythmic, successive shots could be unrelated and constantly moving, and the images presented could be unpredictable, contradictory and playful. $\underline{23}$ The free reign offered to directors and musicians has increased further as videos have moved from television to websites such as YouTube, allowing the already lively genre to "continually define itself by stretching beyond its own territory." $\underline{24}$

As a "primary marketing mechanism for songs and performers," popular music videos have similar commercial aims to product advertisements. $\frac{25}{}$ But whereas Chanel, Revlon and Yves Saint Laurent's early adverts used 'hard-sell' tactics such as jingles, spoken narration, and product images to explicitly create a connection between the women on screen and the attributes of the fragrance, music video introduced an innovative focus on entertainment and style. $\underline{26}$ Heightened audiovisual relations, whereby sound and image are more closely linked, offered a way to subtly, often subliminally, communicate the advert's message; as Nicholas Cook writes, music is able to create new meanings and connections through its interaction with images and words, without the viewer being conscious of the process - it happens "silently." $\underline{27}$ Although this has been criticised as a "calculated attempt to convince and cajole the viewer" by purposefully making it harder to "recognise ads for what they are," it is precisely this invisible process which makes music video such an effective marketing tool for musicians and their records. $\underline{28}$

Despite the freedom and room for creativity inherent in this new form, in terms of gender representation, music video regularly fell back on many of the stereotypes already present in television advertising, and often continues to do so today. Early analysis of music video from the 1980s and 1990s found men and women shown in stereotypically 'male' and 'female' occupations, and while men were presented as more "adventuresome, aggressive and domineering," women were often portrayed as "affectionate, nurturing, dependent" and frequently shown as "sex objects." $\underline{29}$ In a similar way to perfume advertising, the ability of stereotypically attractive, 'feminine' women to appeal to both male and female consumers is regularly exploited in music video to sell records. This is epitomized by Robin Thicke, T.I. and Pharrell's "Blurred Lines" music video (2013), which is comedic in its shameless use of the female body to gain the audience's attention and boost record sales. Throughout the video, male singers lip-sync, fully dressed in suits, while female models dance topless 
beside them. Their bodies are fragmented and fetishized: breasts, feet, hair and lips are all shown in isolation for the pleasure of the viewer and the men in the video. $\underline{30}$

\section{Visit the web version of this article to view interactive content.}

Video 4. Robin Thicke, "Robin Thicke - Blurred Lines ft. T.I. \& Pharrell (Unrated Version)," March 28, 2013, accessed April 25, 2020, https://www.youtube.com/watch?v=zwT6DZCQi9k.

However, since its inception, many musicians have also used the creative potential of music video to reject gender stereotyping and objectification of women. Queer artists and musicians of colour in particular were at the forefront of these boundary-breaking representations, from the androgyny of David Bowie, Prince and Sylvester in the 1980s to the camp aesthetic of the Pet Shop Boys in the 1990s. .31 Artists such as Madonna and Grace Jones were notorious for music videos featuring shifting identities and constant reinvention of their image. $\frac{32}{}$ More recently, this type of rebellious representation has been pushed further, as increasingly sophisticated technology has allowed greater experimentation. Lady Gaga, for example, conveys complex, nuanced and sometimes conflicting identities in one video, assisted by seamless changes between light, darkness, contrasting colour palettes and settings facilitated by new production and editing technology. $\frac{33}{}$ Her video for "Yoü and I" (2011) uses surrealism to convey a range of versions of herself, thereby questioning the binary representation of gender and sexuality common in both music videos and perfume advertisements. $\underline{34}$

\section{Visit the web version of this article to view interactive content.}

Video 5. Lady Gaga, "Lady Gaga - Yoü And I (Official Music Video)," August 16, 2011, accessed April 29, 2020, https://www.youtube.com/watch?v=X9YMUOWeBwU.

Throughout the video, Gaga exists as both her James Dean-inspired male alter ego Jo Calderone and a 'girl next door', piano-playing version of herself in the same scene with the use of subtle editing. $\frac{35}{}$ These characters respectively embody 'masculine' characteristics - aggressive, beerdrinking, uncouth - and 'feminine' characteristics - long hair, silky, revealing attire and an aura of wide-eyed innocence (see Figures 4-5). 


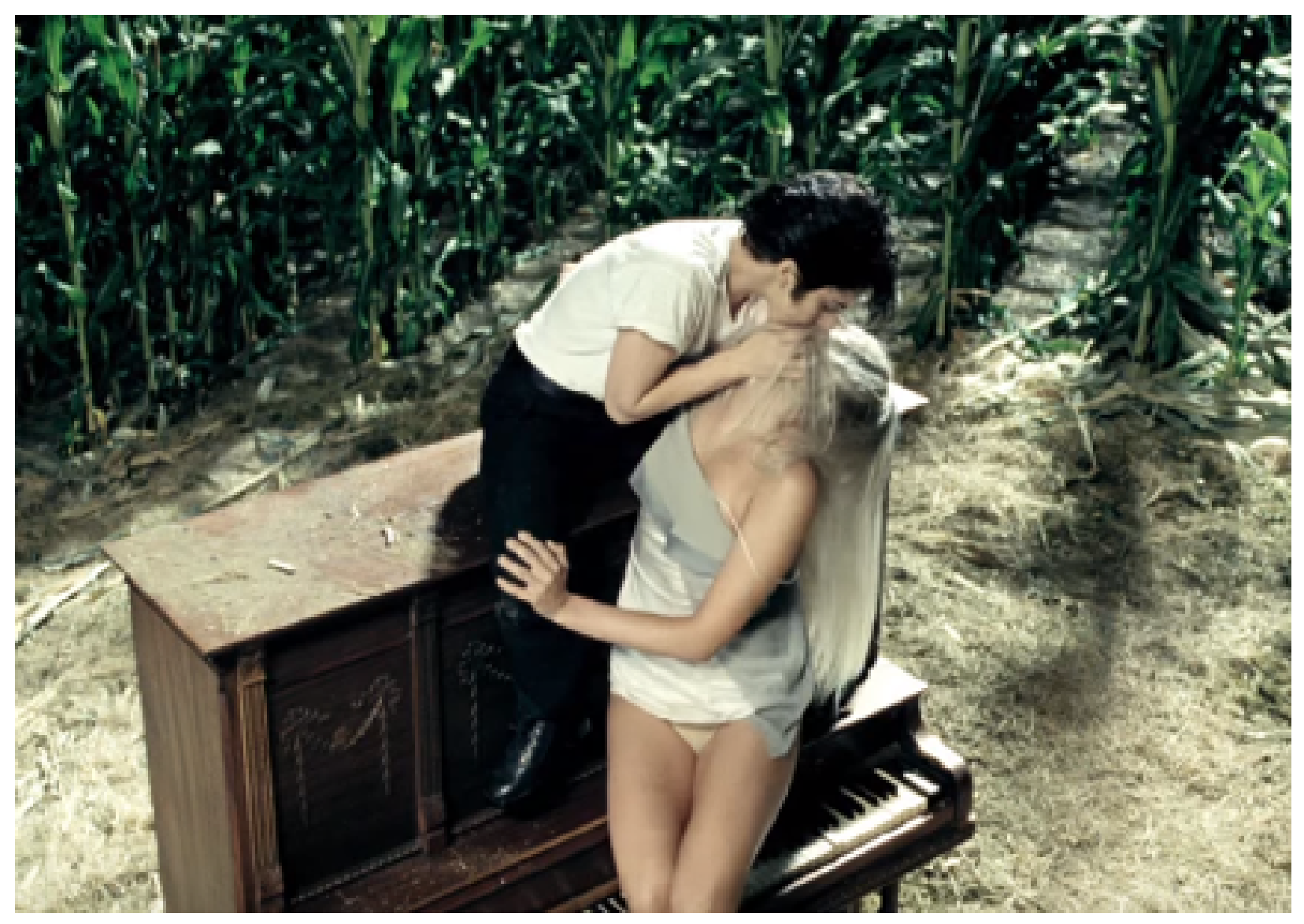




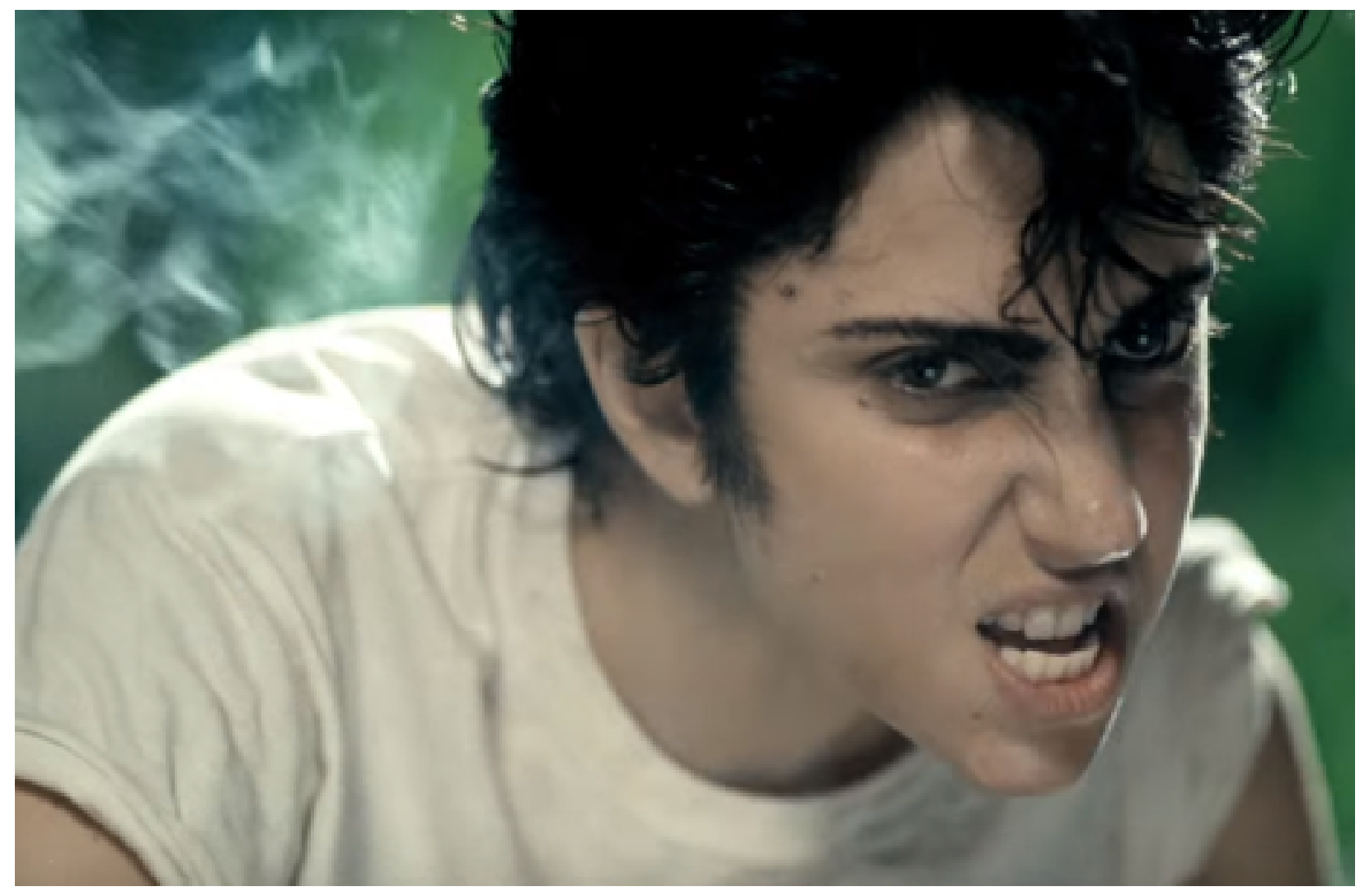

Figures 4-5. Lady Gaga presents masculine and feminine versions of herself within the same scene in her "Yoü And I" music video; screenshots taken from Lady Gaga. "Lady Gaga - Yoü And I (Official Music Video)." YouTube video, 6:21. August 16, 2011. Accessed April 29, 2020. https://WwW. youtube.com/watch?v=X9YMUOWeBwU.

Gaga further pushes the boundaries of gender and sexuality in this video by creating additional inhuman, mechanically-enhanced and amphibious versions of herself. In fleeting moments throughout the video, a mermaid Gaga has sexual intercourse with a human male (4:05), a gothic Vogue Gaga rotates her mechanical arm in sync with the music (1:17-1:19) and a strapped-down, glamorous Frankenstein's monster Gaga is experimented upon by her creator (2:29-2:37).

The fluidity and unnatural appearance of these identities, enabled by developments in CGI and digital post-production techniques, challenge our understanding of human biology. As such, they can undermine the authority placed on "biological differences" in determining binary gender categorisations. $\frac{36}{}$ This type of modulating identity, as Shaviro argues, is symptomatic of our digital media age, whereby there are no "fixed or pre-given forms" and images can be continually manipulated. $\frac{37}{}$ The image of Gaga acts as a node due to her recognisability as a pop culture icon, on which digital processes and radical transformations take place. $\underline{38}$ Like many perfume advertisements and music videos, "Yoü and I" is a love story centred around a celebrity icon. But rather than using the allure of her sexualised image to express this narrative, like Chanel's Deneuve advert, Gaga modulates through a range of personas. Her disparate, constantly shifting identities are never reconciled or connected, resulting in a sense that her music and videos offer a space for anyone who does not fit the 
stereotypical narratives of gender and sexuality commonly presented by television, film and advertising. Whereas perfume adverts commonly use the sexualised female image to sell perfumes to both men and women, Gaga sells her records to the wider LGBTQ+ community by using technology to constantly redefine herself.

Gaga's identity play is extremely overt, consciously shocking and politically charged, as is commensurate with her broader persona and musical output. However, other artists utilise the enhanced audiovisual possibilities and creative freedom of music video to shape more subtly rebellious representations. Sia's “Chandelier" (2014) music video, for example, features a strippedback setting, muted colour palette and child dancer Maddie Ziegler. $\underline{39}$

\section{Visit the web version of this article to view interactive content.}

Video 6. Sia, "Sia - Chandelier (Official Music Video)," May 6, 2014, accessed April 17, 2020, https://www.youtube.com/watch? $\mathrm{v}=2 \mathrm{vj}$ PBrBU-TM.

Notably, unlike the perfume adverts and music videos discussed previously, the celebrity image in Sia's video is more understated - she does not appear in her own music video. Instead, her persona is evoked through Ziegler. Dressed in a blond wig to match the one typically worn by Sia in interviews, Ziegler arguably acts as an expression of the 'inner child' or inner life of the celebrity, free from the connotations of fashion or fame. This ties in with Sia's broader 'anti-fame' approach and quest for anonymity in public appearances, interviews and videos, characterised by wigs which conceal her face. Although Sia's desire to avoid fame purportedly stems from a need to protect herself, it actually "contributes to a narrative that highlights her dramatic personal life;" a narrative which, as Kai Arne Hansen argues, is expressed through "the aesthetics of audiovisual production and lyrical content" of her videos. $\frac{40}{}$ While the Chanel advert used the illusion of revealing Deneuve's inner feelings whilst still capitalising on her sexualised image and film star persona, Sia's image is channelled through Ziegler.

As a result, "Chandelier" is able to explore intimate aspects of Sia's experiences and emotions in a way which avoids objectification or fetishization and is more accurate in its depiction of women as multifaceted individuals with their own ambitions, strengths and failings. This is largely due to the sense of free, uninhibited expression and physicality created by Ziegler's performance and the camera movements and editing used to showcase them. Throughout the video, choreography by Ryan Heffington embodies the music through unconventional and unpredictable actions. At the outset, we see Ziegler's whole body, suspending herself in a doorway (0:11-0:19); an unnatural pose which makes her appear larger than life. From this moment of stillness, the video dynamically unfolds as tracking shots trace Ziegler taking control of the space. There is an animalistic, wild quality to many of her movements: crawling on all fours, a hunched back, punching, kicking and contortions are all present. 
Athletic, aggressive movements are juxtaposed with balletic spins (0:44-0:46). Her facial expressions rapidly change to portray extremes of emotion, including snarling anger (1:46-1:48) and forced happiness (3:29-3:42). These mirror Sia's vocals, which feature contrasting broken, gravelly verses and powerful choruses. The aim is not to portray a conventionally attractive or pretty face, but a more relatable, expressive one.

The fluid camera movement responds to Ziegler's powerful dominance of the room, to the extent that she dictates its rapid panning, tracking, and flow from ground-level to ceiling height. Ziegler regularly outpaces the camera as it frantically tries to keep up with her, falling out of shot and escaping any attempt at fixing her experience within the frame (1:05-1:08). We get the sense that she cannot be contained by the type of close-up, picturesque framing which shrouds Deneuve's image in seductive, but false, intimacy. Like Deneuve, she is clearly 'lost in feelings', but these emotions are being relentlessly projected onto her surroundings in a way which reflects the defiant lyrics and emphatic vocals within the song. Her emotions and physical actions control the cinematic framing of her experience, rather than vice-versa; in stark contrast to the selective objectifying of body parts featured in the perfume adverts above. This is an excellent example of the heightened audiovisual relations possible in music video, whereby sound, movement and aesthetics of the production unfold symbiotically. This flexibility and fluidity enable a multifaceted and complex portrayal of femininity, which encompasses strength, anger, athleticism and a dominance of the space more common to masculine representations.

Both Lady Gaga and Sia's videos push the conventional limitations placed on gender and femininity, offering examples of the ways in which technological advances and a more experimental vision can be used to challenge stereotypical representations of women in mainstream media. Given perfume advertising's reliance on such conventional portrayals, an emulation of this aesthetic and political rebellion could provide a radically new commercial model. This potential is harnessed in Kenzo's 2016 "Kenzo World" fragrance advert, whereby the spirit of nonconformism embodied by musicians like Gaga and Sia, as well as the audiovisual techniques introduced by the wider music video genre, are used in combination to reject the restrictive model of woman as a sexual, objectified 'reward' prevalent in much perfume advertising.

\section{Breaking the Mould: Kenzo's 2016 Fragrance Advert}

"When we think about perfume campaigns, we think about a pretty girl with a bottle. This clip is exactly the opposite" - Margaret Qualley $\underline{\underline{41}}$ 


\section{Visit the web version of this article to view interactive content.} Video 7. Beautybox, "Perfume Kenzo World," August 4, 2017, accessed April 30, 2020, https://www.youtube.com/watch?
v=176h1703FEl.

Kenzo's 2016 advert for the "Kenzo World" fragrance offers a radical alternative to the previous models of perfume advertising. $\frac{42}{}$ Directed by notable film and music video director Spike Jonze, this commercial utilises features of the music video aesthetic such as audiovisual synchronicity and surrealism to subvert notions of acceptable 'feminine' behaviour. Rather than portraying the advert's star, Margaret Qualley, as a desirable, sexual object, Jonze creates an association between the confidence, fearlessness and freedom of expression she exhibits and the perfume. This rebellious spirit is reflected in choreography by "Chandelier" choreographer Ryan Heffington; the transmedia collaborations between professionals such as Heffington and Jonze are symptomatic of the wider fluidity and cross-fertilisation between film, music video and advertisement. $\underline{43}$ By exploring this example in close detail, it is possible to suggest the ways in which the music video aesthetic can be used as a gateway to more varied gender representations in advertising.

The advert opens at a black-tie event, with tables of guests listening to an unseen male speaker. The frame is filled with people, but a slow zoom brings the viewer's focus onto a single female guest, played by Margaret Qualley. The use of Qualley to front the commercial, a relative unknown compared to the likes of Deneuve and Jennifer Lawrence, is immediately significant. As with Sia's "Chandelier," avoiding the celebrity persona mitigates the types of associations which the Chanel Deneuve capitalises on. Although Qualley is a model and actress, she is not the type of iconic celebrity who can be commodified by manipulating the unknowable/overfamiliar paradox of their persona; a process exemplified by the Chanel advert. The model of fantasy/reward, created through an illusion of intimacy with a sexualised celebrity, is therefore avoided from the outset in this Kenzo advert.

In the opening scene, Qualley nods and laughs politely in reaction to the speech but looks uncomfortable; she might be bored, tired, or feeling overwhelmed by the formality of the event. As she excuses herself from the room and walks into the hallway (0:28), a wide angle emphasises the size of the space, immediately relieving the claustrophobia of the previous shot. A closeup of Qualley looking directly into the camera reveals that she is crying (0:54), while the sound of synthesised violins leads the viewer to perceive her as helpless and vulnerable. At this moment, a traditional perfume advert narrative could still take place. Instead, the tension is suddenly broken as Qualley begins to move her eyes in sync with manipulated tongue clicking sounds (1:02), launching the beginning of a music video which consists of Qualley sprinting, lunging and throwing herself around the venue's empty halls in a similar manner to Ziegler, subverting the expectations set up by the advert's opening scenes. 
The song used in this advert immediately challenges pre-existing perceptions of fragrance advertisements. Written specifically for Kenzo's advert, Sam Spiegel, Ape Drums and Assassin's collaborative track "Mutant Brain" (2016) features elements of hip-hop, Jamaican dancehall and electronic dance music (EDM) - a stark contrast to the jingle approach found in Revlon's "Charlie" advert or, more recently, Maybelline's “maybe she's born with it /maybe it's Maybelline.” $\underline{44}$

\section{Visit the web version of this article to view interactive content.}

Video 8. PinkCoutureVids, "Maybelline "Dream Wonder" Liquid Foundation TV Commercial (Fall 2014)," August 6, 2014. accessed July 3, 2020, https://www.youtube.com/watch?v=06ISk000-tk.

As is expected from a music video, Qualley's movements are designed to reflect the tempo, rhythms, vocal quality and contrasting timbres of the track in a comparable way to "Chandelier." Assassin's strong Jamaican accent, the driving pulse, synthesised sounds, EDM climaxes and drops are incongruous with the lavish, refined setting and majority white, middle-class characters of the first scene in the advert, thereby providing a space in which subversive behaviours can take place. However, while this point of incongruity and tension is rebellious in itself, it is notable that Qualley herself still represents white, middle-class femininity, and as such her actions are only subversive within these boundaries. The advert does not choose to present a Jamaican female experience, but instead uses the racial 'otherness' of Assassin's accent and musical influences to destabilise our expectations of a woman who represents an 'ideal' of female beauty - young, white, able-bodied, and cis-gendered.

Qualley is initially shown to be conventionally feminine, wearing a fitted gown and make-up, whilst smiling congenially with the women on either side of her - the viewer does not expect her to break from the role of well-mannered, attractive dinner guest, nor would they associate her with this style of music. Therefore, the perfume advertising conventions outlined previously are compromised by a musical style that embodies features traditionally associated with masculinity. As her movements and the rhythmic editing of shots is driven entirely by the beat and content of the music, a key feature of music video, Qualley embodies the masculine attributes of "Mutant Brain" and rejects the behavioural gender norms expected of her. $\underline{45}$ For example, the emergence of the animalistic "rakakaka" motif drives increasingly outlandish movements from Qualley (1:05), who grits her teeth and suddenly transitions from light-hearted facial expressions to throwing her head and body backwards as if in a state of demonic possession; an unsettling visual reminiscent of Ziegler's erratic movements in “Chandelier" (see Figures 8-10). 

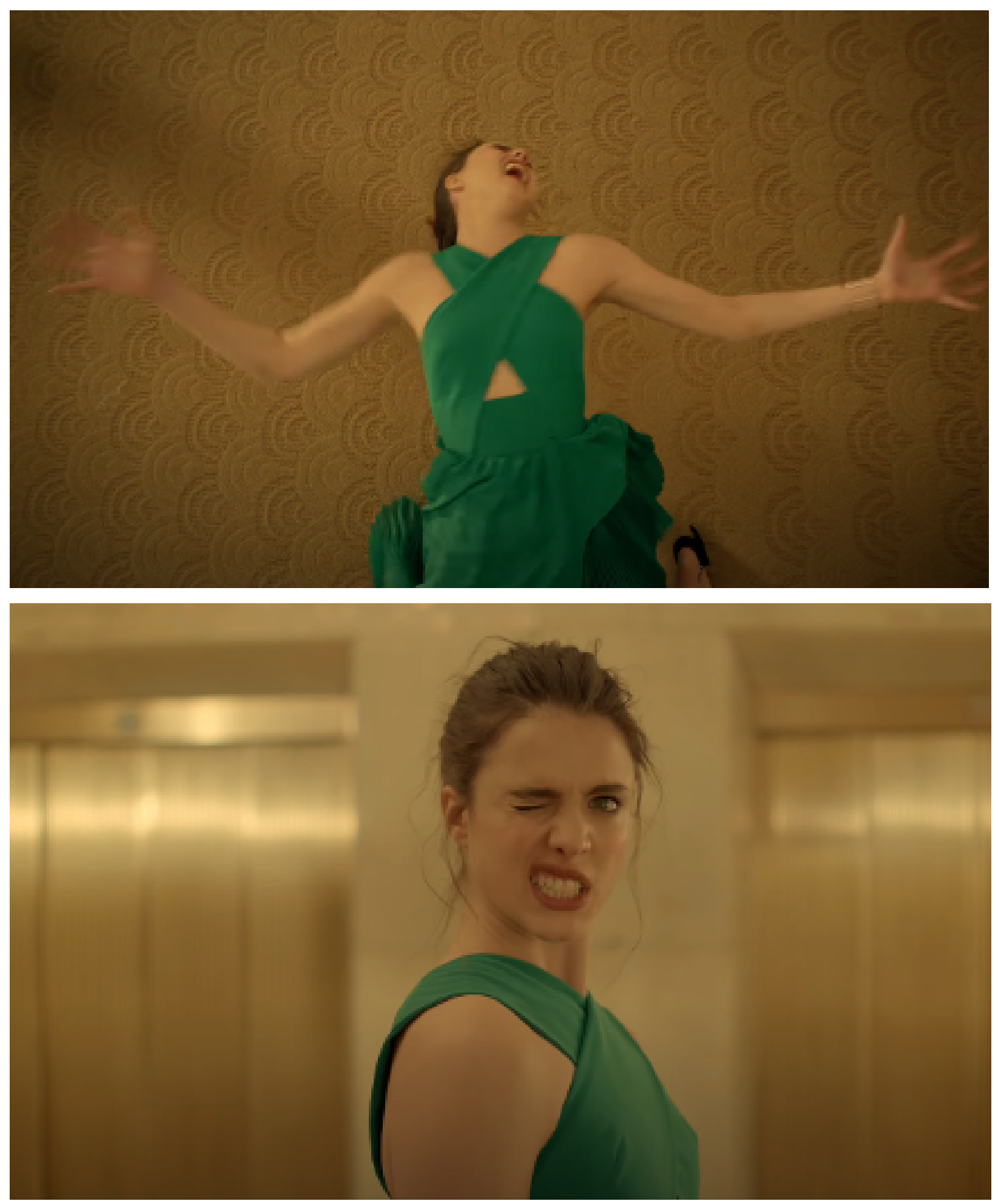


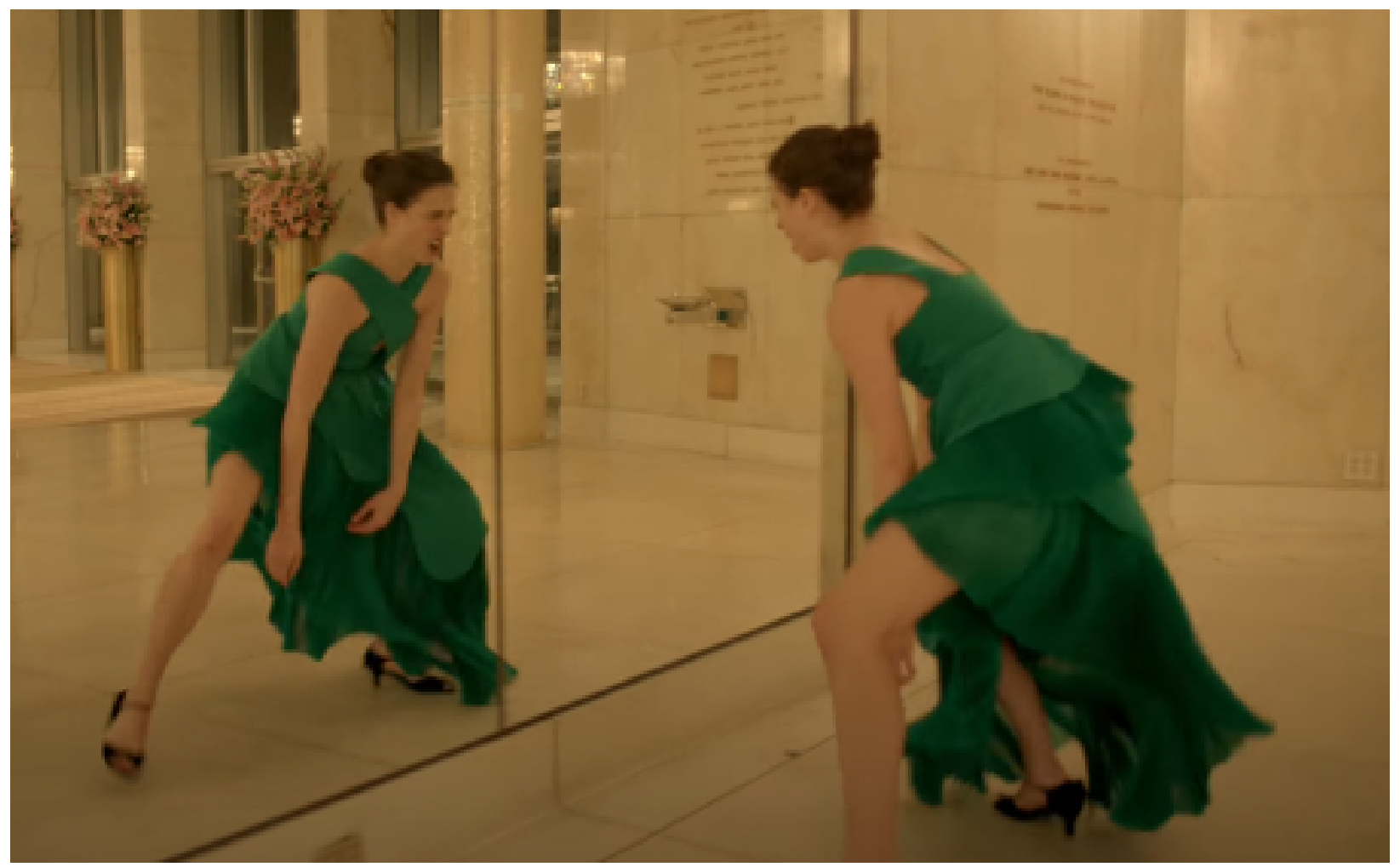

Figures 8-10. Dancer Margaret Qualley in "Kenzo World"; screenshots taken from Beautybox. "Perfume Kenzo World." YouTube video, 3:46. August 4, 2017. Accessed April 30, 2020. https://www.youtube.com/watch?v=176h1703FEl.

As this motif rises to the forefront of the audio, Qualley's movements become threatening, including screaming directly into the camera before purposefully striding towards it as the beat drops and the song lyrics begin (1:21). Qualley's huge leg movements, a low camera angle and Assassin's deep vocal combine to create the impression of being stalked or aggressively approached by a wild animal. The femininity represented by her dress and demeanour in the first scene is therefore destabilised by behaviours not perceived as appropriate for her gender, the formal setting, or a perfume advertisement. In comparison to Revlon's “Charlie” commercial, whereby Shelley Hack's movements are designed to enhance her attractiveness, Kenzo's advert presents a woman whose actions do not revolve around alluring the opposite sex.

Furthermore, the choreography largely avoids conventional dance movements or postures aimed at making Qualley look attractive or graceful, focussing instead on embodying the ferociousness of the music. At 2:08, she is an aggressive fighter, kicking and punching in coincidence with a machine-gunlike electronic sound effect. At 2:38, the tension between 'acceptable' female behaviour and a desire for free expression is displayed, as Qualley struggles to keep her wildly flailing arm and leg under control - an apologetic, embarrassed smile reveals her knowledge that this behaviour is outside of the realms considered 'normal.' However, there is also a sense in which she appears controlled by the music in this moment, particularly as she shakes her torso and rolls her wide eyes back (2:44); this 
music is so 'other' to Qualley that there is a tension between her using it to express herself and it overpowering her.

This conflict between female behavioural norms and liberated movement is also reflected sonically towards the end of the commercial: as Qualley appears on stage in an empty auditorium, fragments of a lyrical piano melody compete with the 'rakakaka' motif, motivating her to display balletic movements which are complimented by the elegant flow of her dress (3:07). However, this is short-lived as Qualley falls backwards off the edge of the stage to the isolated sound of an electronic beep, reminiscent of an analogue television 'no signal' tone or malfunctioning technology - Qualley was attempting to function within accepted notions of 'femininity,' but her overriding behaviour is defective.

Throughout the video, Qualley also demonstrates physical prowess not typically associated with femininity, by sprinting up stairs (1:50), overpowering an unsuspecting man (2:20) and somersaulting (3:22), in direct parallel with the athleticism and unrestrained power of Ziegler's 'Chandelier' performance. Qualley goes a step beyond Ziegler, shooting lasers from her fingertips accompanied by video game gun sound effects (2:29) and defying gravity (3:28); by crossing over into video game superpowers, Qualley inhabits a male-dominated space and defies the common presentation of female gaming characters as sexualised, objectified beings. These supernatural elements in particular are afforded by the sense of freedom and experimentalism which music video brings to advertising, as seen in Gaga's "Yoü and I" video and can be traced back to Spike Jonze's earlier works. His video for Fatboy Slim's "Weapon of Choice" (2001), for example, features actor Christopher Walken flying, somersaulting and dancing around a hotel in a similar way to Qualley, thereby enhancing particular features of the song such as the climactic ending (3:23). $\underline{46}$

By applying the experimentalism and freedom of movement in "Weapon of Choice" to a perfume advert, Jonze rejects the notion of the woman as passive sexual object to be looked at, as exemplified by Chanel's Catherine Deneuve advert, and allows Qualley to embody active, dominant and aggressive attributes typically associated with masculinity. $\underline{47}$

Like Sia's "Chandelier" music video, the use of fluid camera movement throughout Kenzo's advert allows Qualley to further reject the stillness associated with being treated as a sex object - as seen in the photographic quality of Deneuve's Chanel advert - and instead become a driving figure who moves purposefully around the space. $\underline{48}$ As Qualley sprints through the building, tracking shots are constantly employed, coupled with digital erasing of the camera as she runs past numerous mirrors (1:52-1:55). These techniques allow the viewer to visually experience the flow of the music - a common feature of music video, including Sia's "Chandelier" - and to feel seamless freedom of movement alongside the lead character. $\underline{49}$ This represents a contrast to the still shot of seated characters in the opening scene, where movement is derived only from a slow camera zoom. The difference between 
these two filming styles thereby enhances the sense of breaking with the restrictive behaviours expected of an attractive woman in perfume advertising, alongside Qualley's physical movements and the 'masculine' qualities of the music.

In a final act of rebellion at the end of the advert, Qualley escapes the confines of the venue and runs towards a floating, floral effigy of the Kenzo logo (3:16). The use of flowers in this scene creates a visual representation of the 'Kenzo World' scent, thereby drawing the viewer's attention to the product being sold, which has been absent throughout the rest of the advert. The presence of flowers also evokes associations of femininity and sexuality, particularly through the use of pink blooms to frame Qualley as she runs towards the Kenzo 'eye' (3:18-3:21). However, these associations are subverted as Qualley throws herself through the centre of the floral 'eye', causing the petals to disperse in a manner both reflecting the act of spraying perfume onto oneself, and the act of physically and mentally breaking the boundaries imposed by society (3:29); thereby creating a connection between the product and the rebellious behaviours exhibited throughout the advert.

The subversive attitude of the "Kenzo World" advert, conveyed through the music video-inspired synchronicity of images, music and editing, therefore creates a new model for fragrance advertisements. Rather than objectifying female bodies to "sell products to both women and men on the basis of their sexual appeal to men," this advert presents a woman who rejects the boundaries placed on her by society. $\underline{50}$ While the Revlon and Yves Saint Laurent adverts attempted to represent the 'modern woman' in order to appeal to her, the fetishization of fragmented body parts and emphasis on beauty undermined elements of progressiveness. However, in Kenzo's advert, audiovisual fluidity, an unconventional, masculine soundtrack and the creative licence afforded by music video allow a rebellious portrayal of an unrestricted, free woman. Consumers are thus inspired to buy the product in order to be like Qualley, not because she is sexually attractive like Catherine Deneuve or Shelley Hack, but because her behaviour represents a break with the norm. The advert does not attempt to move away from representations of white, middle-class and cis-gendered female experience which dominate the industry, however - these elements are still very much in place. Yet within these limits, Kenzo's perfume can still be seen as an alternative to larger brands such as Chanel, Revlon and Yves Saint Laurent, and the narratives their adverts present.

\section{Completing the circle: Taylor Swift's "Delicate"}

Nowadays, with advertisements, films and music videos often sharing the same online spaces, twentieth-century modes of experiencing television and cinema are being reimagined. Media are both 
adapting to and shaping a "media swirl" of "accelerating aesthetics," as Vernallis describes it, which features increasing cross-fertilisation and fluidity between previously distinct genres. $\frac{51}{}$ Films can start to look like video games, adverts can look like YouTube clips, and music videos can look like films. The "Kenzo World" advert offers an example of direct crossover. In form, structure and aesthetics, it resembles a music video, and was envisioned by a director and choreographer who have worked in that genre. However, music video's influence on advertising - and the possible political implications I have suggested - is not one-sided or isolated. The Kenzo advert was produced for use across all of the digital platforms mentioned above, as well as television, and as such is part of a more complicated web of intersecting media influences.

It is no surprise, therefore, that hallmarks of the Kenzo perfume advert can also be traced through into another music video. Taylor Swift's "Delicate” video (2018) shares the same narrative, whereby a woman breaks free from the pressures of society and acts freely as though nobody is watching. $\underline{52}$

\section{Visit the web version of this article to view interactive content.}

Video 9. Taylor Swift, "Taylor Swift - Delicate," March 11, 2018 , accessed April 5, 2020, https://www.youtube.com/watch? $\underline{v=t C X G J Q Y Y Z} \underline{Y} \underline{.}$.

Like Sia's “Chandelier," "Delicate" has a further dimension surrounding Swift's fame as a pop star, the desire to become invisible in order to be oneself, and the need as a famous female to be protected and therefore separated from normal life. The video opens with Swift at a public event, plagued by paparazzi and flanked by bodyguards. In the bathroom, we see her drop the façade, expressing her frustration and personality by pulling faces away from the public eye (0:47-1:01), before discovering she has magically become invisible. Like the Kenzo commercial, Swift's newfound freedom is expressed through choreography and digital editing techniques, and the parallels in the execution are so striking that they caused controversy following the video's release. $\underline{53}$ Digital post-production editing removes her image, and that of the camera, from the bathroom mirror (1:04-1:11); a technique also used in the Kenzo advert. Swift's movements are almost identical to those created by Heffington in his choreography for both Sia's "Chandelier" and Kenzo: flat-footed kicking, marching and stomping (2:042:07), animalistic squatting and a hunched body (1:43-1:47), all interspersed with more conventional ballet movements (1:53-1:57) (see Figures 11-12). 

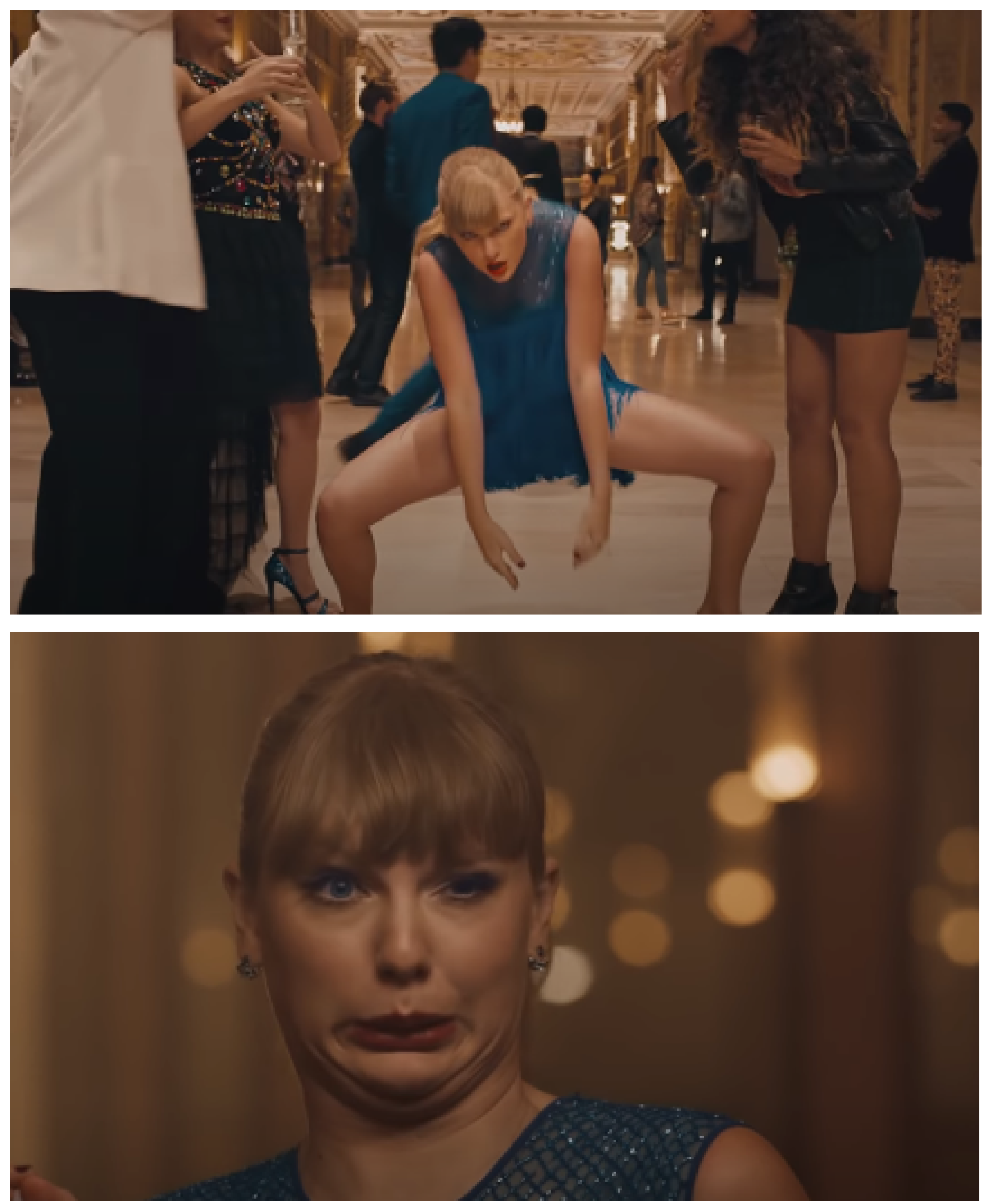

Figures 11-12. Taylor Swift's "Delicate" has hallmarks of "Kenzo World"; screenshots taken from Beautybox. "Perfume Kenzo World." YouTube video, 3:54. August 4, 2017. Accessed April 30, 2020. https://www. youtube.com/watch?v=176h1703FEl.

Swift's video also features tracking shots and a fluidity of movement common to these two works, which similarly creates the sense of her as a driving force within the space and as an active, fully three- 
dimensional woman.

While the "Delicate" aesthetic is undeniably reminiscent of Kenzo's commercial, it is also in-keeping with Swift's commercially successful persona. Her music videos, social media and TV appearances often present an awkward, 'dorky' personality and an ability to not take herself seriously. Like Deneuve's Chanel advert, therefore, "Delicate" achieves its commercial aims by allowing viewers to believe they are seeing the 'real' Swift. However, Swift's 'relatable' persona is often criticised as insincere or fake, a perception which feeds into accusations of plagiarism in her "Delicate" video. What is at stake here is the sense in which Swift has appropriated a more rebellious representation of femininity and sublimated it into her own 'dorky' brand. In doing so, both her persona and the way in which it is conveyed appear false - if she is drawing so heavily on another source, how can we believe in her authenticity? Swift's fame is central to this critique in a way which the Kenzo advert and Sia's "Chandelier" avoid, both starring dancers and forcing us to focus on the pioneering aspects of their representations. Female celebrities suffer the fate of a public who feel they intimately know them, or more to the point, have fixed ideas of what they want them to be. Regardless of how aesthetically or politically ground-breaking their representations of themselves are, they are always reducible to the “idealized stillness [...] and perfection of form" demanded of celebrity icons. $\underline{54}$

"Kenzo World," "Chandelier," "Yoü and I" and "Delicate" channel the techniques and creative freedoms of music video to present a female who moves beyond the expectations perpetuated within society. By taking a more abstract, imaginative approach which avoids the tropes surrounding perfume and sexuality, Kenzo's commercial in particular provides new ways of appealing to a female audience; namely, by associating the brand with a break from the norm and a flexible approach to notions of 'feminine' behaviour and gender roles. Rather than selling the illusion of intimacy and romance, Kenzo blends music and visuals to present a different type of woman; one whose dominant, active, loud, and uncompromising characteristics are traditionally associated with masculinity. In this case, the aesthetics of music video are therefore enabling a new model for perfume advertising.

However, as "Delicate" shows, this type of representation can become complicated by notions of fame and broader multimedia influences and associations. These media productions are part of a broader marketing framework, whereby every artistic choice is arguably aimed at soliciting purchases from a particular demographic. Each woman presented becomes part of a brand or, in the case of Taylor Swift, Sia and Lady Gaga, a brand in themselves. But regardless of the motivations for creating unconventional portrayals, they continue to be valuable. In a digital era where the constant presence of adverts is inevitable, the 'acceptable notions' of femininity presented by commercially-driven mainstream media platforms are pervasive and damaging to women's perception of themselves particularly where they only represent a white, cis-gendered female experience. $\underline{55}$ Given the history of stereotyping and objectifying women in perfume advertising, commercials which present women who 
are complex, multi-faceted beings are welcome regardless of the intention behind their construction. While "Kenzo World" draws upon the creative audiovisual techniques of music video to produce a brand-new model for perfume advertising that champions unconventional, uncompromising femininity, "Blurred Lines" is evidence that these technologies and aesthetics are not politically radical in themselves. Music video can facilitate more nuanced and progressive representations of women but only for those brave enough to challenge perfume advertising's entrenched exploitation of women's bodies.

\section{Bibliography}

Baxter, Richard L., Cynthia De Riemer, Ann Landini, and Larry Leslie. "A Content Analysis of Music Videos." Journal of Broadcasting \& Electronic Media 29, no. 3 (1985): 333-40.

Butler, Judith. Gender Trouble: Feminism and the Subversion of Identity. New York: Routledge, 1999. Carter, Cynthia. "Sex/Gender and the Media: From Sex Roles to Social Construction and Beyond." In The Handbook of Gender, Sex, and Media, edited by Karen Ross, 365-82. Malden: Wiley-Blackwell, 2012.

Cook, Nicholas. "Music and Meaning in the Commercials." Popular Music 13, no. 1 (1994): 27-40.

Grau, Stacy Landreth and Yorgos C. Zotos. "Gender Stereotypes in Advertising: A Review of Current Research." International Journal of Advertising 35, no. 5 (2016): 761-70.

Gunter, Barrie. “Gender Role Portrayals in Advertisements." In Television and Gender Representation, 33-50. London: John Libbey, 1995.

Hansen, Kai Arne. “Holding On For Dear Life: Gender, Celebrity Status, and Vulnerability-On-Display in Sia's 'Chandelier'." In The Routledge Research Companion to Popular Music and Gender, edited by Stan Hawkins, 89-101. London: Routledge, 2017.

Hawkins, Stan. "Introduction: Sensing Gender in Popular Music." In The Routledge Research Companion to Popular Music and Gender, edited by Stan Hawkins, 1-12. London: Routledge, 2017.

“Hollywood Topic A-Plus: Whole Town's Talking About Marilyn Monroe." Life. April 7, 1952. Accessed June 26, 2020. https://oldlifemagazine.com/april-07-1952-life-magazine.html. 
Klein, Bethaney. As Heard on TV: Popular Music in Advertising. Farnham: Ashgate, 2009.

Korsgaard, Mathias Bonde. "Music Video Transformed." In The Oxford Handbook of New Audiovisual Aesthetics, edited by Claudia Gorbman, John Richardson and Carol Vernallis, 502-24. Oxford: Oxford University Press, 2013.

March, Bridget. "Exclusive: Zoë Kravitz on the importance of 'being unapologetically yourself'." Harper's Bazaar. September 19, 2018. Accessed July 1, 2020.

https://www.harpersbazaar.com/uk/beauty/fragrance/a23300055/zoe-kravitz-ysl-beauty-interview/.

McClary, Susan. Feminine Endings: Music, Gender, and Sexuality. Minneapolis: University of Minnesota Press, 1991.

McCracken, Katie, Ana Fitzsimons, Sarah Priest, Sylvia Girstmair and Brenda Murphy. Gender Equality in the Media Sector. Brussels: European Parliament, 2018.

Mulvey, Laura. "Visual Pleasure and Narrative Cinema." In Visual and Other Pleasures. $2^{\text {nd }}$ ed, 14-27. Basingstoke: Palgrave Macmillan, 2009.

Reed, Sam. “Taylor Swift's ‘Delicate’ Video Looks a Lot Like Spike Jonze's Kenzo

Perfume Ad." Hollywood Reporter. December 3, 2018. Accessed April 5, 2020.

https://www.hollywoodreporter.com/news/taylor-swifts-delicate-video-looks-a-lot-like-spike-jonzeskenzo-perfume-ad-1093880.

Richford, Rhonda. "Watch 'The Nice Guys' Star Margaret Qualley Dance Her Way Through Spike Jonze's Kenzo Film." Hollywood Reporter. August 29, 2016. Accessed August 7, 2020.

https://www.hollywoodreporter.com/news/margaret-qualley-spike-jonzes-kenzoworld-923576.

Seidman, Steven A. "An Investigation of Sex-Role Stereotyping in Music Videos." Journal of Broadcasting \& Electronic Media 36, no. 2 (1992): 209-16.

Shaviro, Steven. Post-Cinematic Affect. Winchester: Zero Books, 2010.

Signorelli, Nancy, Douglas McLeod and Elaine Healy. "Gender Stereotypes in MTV Commercials: The Beat Goes On." Journal of Broadcasting and Electronic Media 38, no. 1 (1994): 91-101.

Taylor, Timothy D. The Sounds of Capitalism: Advertising, Music, and the Conquest of Culture. Chicago: University of Chicago Press, 2012.

“THE MEDIA BUSINESS; How MTV Has Rocked Television Commercials." The New York Times. October 9, 1989. Accessed April 20, 2020. https://www.nytimes.com/1989/10/09/business/the-media-businesshow-mtv-has-rocked-television-commercials.html. 
Trampe, Debra, Diederik A. Stapel and Frans W. Siero. "The Self-Activation Effect of Advertisements: Ads Can Affect Whether and How Consumers Think about the Self." Journal of Consumer Research 37, no. 6 (2011): 1030-1045

Vernallis, Carol. Experiencing Music Video: Aesthetics and Cultural Context. New York: Columbia University Press, 2004.

Vernallis, Carol, Holly Rogers and Lisa Perrott, eds. Transmedia Directors: Artistry, Industry and New Audiovisual Aesthetics. London: Bloomsbury, 2020.

Vernallis, Carol. “The Kindest Cut: Functions and Meanings of Music Video Editing." Screen 42, no. 1 (2001): 21-48.

Vernallis, Carol. Unruly Media: YouTube, Music Video, and the New Digital Cinema. Oxford: Oxford University Press, 2013.

Wallis, Cara. "Performing Gender: A Content Analysis of Gender Display in Music Videos." Sex Roles 64, no. 3 (2011): 160-72.

Whiteley, Sheila. "Seduced By The Sign: An Analysis of the Textual Links Between Sound and Image in Pop Videos." In Sexing the Groove: Popular Music and Gender, edited by Sheila Whiteley, 259-76.

London: Routledge, 1997.

\section{Media Cited}

Beautybox. "Perfume Kenzo World." YouTube video, 3:46. August 4, 2017. Accessed April 30, 2020. https://www.youtube.com/watch?v=176h17o3FEI.

Chanel. "Whispered - Chanel No. 5." YouTube video, 0:31. September 26, 2012. Accessed April 19, 2020. https://www.youtube.com/watch?v=TGVNGoMXE2c.

Chanel. “Chanel Nº. 5: The One That I Want - The Film." YouTube video, 3:16. October 14, 2014. Accessed May 21, 2020. https://www.youtube.com/watch?v=8asRWe5XNw8.

Christian Dior. “Dior Sauvage - The New Fragrance (Official Director's Cut).” YouTube video, 1:20.

September 1, 2015. Accessed April 18, 2020. https://www.youtube.com/watch?v=LnoumTpLMfk.

Christian Dior. "JOY by Dior - The new fragrance." YouTube video, 1:00. September 1, 2018. Accessed May 19, 2020. https://www.youtube.com/watch?v=1CRihg1X89A. 
Christian Dior. "Miss Dior - The New Eau de Parfum." YouTube video, 0:45. September 2, 2017. Accessed April 17, 2020. https://www.youtube.com/watch?v=h4s0llopKrU.

Darian Glover. “Revlon Charlie Commercial (April 2, 1979).” YouTube video, 0:30. May 14, 2009. Accessed April 26, 2020. https://www.youtube.com/watch?v=t1WX9znN7CE.

Jimmy Choo. "Shimmer in the Dark: Jimmy Choo CR18 Featuring Cara Delevingne." YouTube video, 1:48. November 9, 2017. Accessed June 29, 2020. https://www.youtube.com/watch?v=DPrRRgagggg.

Lady Gaga. “Lady Gaga - Yoü And I (Official Music Video).” YouTube video, 6:21. August 16, 2011. Accessed April 29, 2020. https://www.youtube.com/watch?v=X9YMUOWeBwU.

Madonna. "Justify My Love (Official Music Video)." YouTube video, 5:00. October 26, 2019. Accessed May 12, 2020. https://www.youtube.com/watch?v=Np Y740aReI.

Paco Rabanne. "Pure XS For Her / Starring Emily Ratajkowski | PACO RABANNE." YouTube video, 0:47. September 10, 2018. Accessed May 19, 2020. https://www.youtube.com/watch?v=-6jK Nzb9HQ.

PinkCoutureVids. "Maybelline "Dream Wonder" Liquid Foundation TV Commercial (Fall 2014)." YouTube video, 0:30. August 6, 2014. Accessed July 3, 2020. https://www.youtube.com/watch? v=061Sk000-tk.

Robatsea2009. “Rive Gauche Perfume sexy 1979 TV commercial.” YouTube video, 0:30. August 14, 2012. Accessed April 29, 2020. https://www.youtube.com/watch?v=-k-SMhod7J吕.

Robin Thicke. “Robin Thicke - Blurred Lines ft. T.I. \& Pharrell (Unrated Version)." YouTube vid 4:32. March 28, 2013. Accessed April 25, 2020. https://www.youtube.com/watch?v=zwT6DZCQi9k.

Sia. “Sia - Chandelier (Official Music Video)." YouTube video, 3:51. May 6, 2014. Accessed April 17, 2020. https://www.youtube.com/watch?v=2vjpBrBU-TM.

Skint Records. "Fatboy Slim - Weapon Of Choice [Official Video]." YouTube video, 3:51. May 21, 2010. Accessed April 26, 2020. https://www.youtube.com/watch?v=wCDIYvFmgW8.

Taylor Swift. “Taylor Swift - Delicate.” YouTube video, 3:54. March 11, 2018. Accessed April 5, 2020. https://www.youtube.com/watch?v=tCXGJQYZYJA.

YSL Beauty. "YSL Black Opium 30s." YouTube video, 0:15. Oct 17, 2019. Accessed July 1, 2020. https://www.youtube.com/watch?v=cLVzdPCWvl4. 


\section{Biography}

Emma Payne is an MA Music graduate and is due to commence her $\mathrm{PhD}$ at Cardiff University School of Music in September 2020. Her area of research concerns the role of sound in the media representation of women, with a particular focus on cinema after the digital turn. Her research methodology will integrate empirical audience studies and theoretically-informed textual analysis, in order to test the impact of these representations on lived experiences of gender.

\section{otnotes}

1.

Though the original interview in which Marilyn Monroe produced this quote is unknown, she later referred to it in an interview for Lifemagazine: "Hollywood Topic A-Plus: Whole Town's Talking About Marilyn Monroe." Life, April 7, 1952, 104, accessed 26 June 26, 2020, https://oldlifemagazine.com/april-07-1952-life-magazine.html.

2.

Actress Natalie Portman asks 'what would you do for love?' as she lets us into the most intimate moments of a romantic holiday in Dior's "Miss Dior" (2017) advert;

In Jimmy Choo's "Shimmer in the Dark" advert (2018), scantily clad model Cara Delevingne enjoys being wolf whistled and complimented as she catwalks to the suggestive lyrics of George McCrae's "I Get Lifted";

And model Emily Ratajkowski strips whilst pursued by suited men, desperate to get a glimpse as she perfumes her naked body in Paco Rabanne's "Pure XS For Her" (2018). $\subseteq$

3. Katie McCracken, Ana Fitzsimons, Sarah Priest, Sylvia Girstmair and Brenda Murphy, Gender Equality in the Media Sector (Brussels: European Parliament, 2018), 64.

4. Cara Wallis, "Performing Gender: A Content Analysis of Gender Display in Music Videos," Sex Roles 64, no. 3 (2011): $161 . \sqcup$ 
5. Cynthia Carter, "Sex/Gender and the Media: From Sex Roles to Social Construction and Beyond," in The Handbook of Gender, Sex, and Media, ed. Karen Ross (Malden: Wiley-Blackwell, 2012), 365-66. 6. Judith Butler famously suggested that both gender and sex could be perceived as cultural constructs, arguing further that gender is an ongoing 'performance' of behaviours not necessarily connected to sex; therefore, 'subversive behaviours' have the ability to undermine binary perceptions of sex and gender. See Judith Butler, Gender Trouble: Feminism and the Subversion of Identity (New York: Routledge, 1999). $\leftrightarrows$

7. Barrie Gunter, “Gender Role Portrayals in Advertisements," in Television and Gender Representation (London: John Libbey, 1995), 41. $\doteq$

8. Steven Shaviro, Post-Cinematic Affect (Winchester: Zero Books, 2010), 8-10.

9. Ibid., 10.

10.

An exception is Yves Saint Laurent's Black Opium adverts, which have featured more diverse stars such as actress Zoë Kravitz (2018). Kravitz highlighted the significance of her role: 'It's so important for other women of colour to see a reflection of themselves in a high-end brand and see that they are worthy of luxury and represent luxury'. Quoted in Bridget March, "Exclusive: Zoë Kravitz on the importance of 'being unapologetically yourself'," Harper's Bazaar, September 19, 2018, accessed July 1, 2020, https://www.harpersbazaar.com/uk/beauty/fragrance/a23300055/zoe-kravitz-ysl-beauty= interview/.

$\triangleq$

11. This type of research could also build upon previous studies of the impact of beauty product advertising on self-esteem, such as: Debra Trampe, Diederik A. Stapel and Frans W. Siero, "The SelfActivation Effect of Advertisements: Ads Can Affect Whether and How Consumers Think about the Self," Journal of Consumer Research 37, no. 6 (2011): 1030-45.

12. Chanel, "Whispered - CHANEL No 5," September 26, 2012, accessed April 19, 2020, https://www.youtube.com/watch?v=TGVNGoMXE2c. $\doteq$

13. This notion of fixing and objectifying the female image was first introduced by Laura Mulvey in her infamous 1975 essay 'Visual Pleasure and Narrative Cinema'. See Laura Mulvey, "Visual Pleasure and Narrative Cinema," Visual and Other Pleasures, 2nd ed. (Basingstoke: Palgrave Macmillan, 2009), 14-27. $\doteq$ 
14. Laura Mulvey, "Visual Pleasure and Narrative Cinema," in Visual and Other Pleasures, $2^{\text {nd }}$ ed. (Basingstoke: Palgrave Macmillan, 2009), 19-20.

15.

Madonna, “Justify My Love (Official Music Video)," October 26, 2019, accessed May 12, 2020. https://www.youtube.com/watch?v=Np Y740aReI;

Sheila Whiteley, "Seduced by the Sign: An Analysis of the Textual Links Between Sound and Image in Pop Videos," in Sexing the Groove: Popular Music and Gender, ed. Sheila Whiteley (London: Routledge, 1997), 270.

16.

Darian Glover. “Revlon Charlie Commercial (April 2, 1979)," May 14, 2009, accessed April 26, 2020, https://www.youtube.com/watch?v=t1WX9znN7CE.

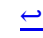

17. Timothy D. Taylor, The Sounds of Capitalism: Advertising, Music, and the Conquest of Culture (Chicago: University of Chicago Press, 2012), 6-7. $\subseteq$

18. Gunter, "Gender Role Portrayals," 41.

19. Ibid., 42. $\subseteq$

20. Robatsea2009, “Rive Gauche Perfume sexy 1979 TV commercial," August 14, 2012, accessed April

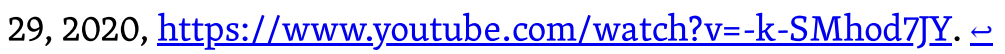

21. Taylor, Sounds of Capitalism, 185-6. $\subseteq$

22. Mathias Bonde Korsgaard, "Music Video Transformed," in The Oxford Handbook of New Audiovisual Aesthetics, eds. Claudia Gorbman, John Richardson and Carol Vernallis (Oxford: Oxford University Press, 2013), 507. $\subseteq$

23. Carol Vernallis, Experiencing Music Video: Aesthetics and Cultural Context (New York: Columbia University Press, 2004), 3-4, 27, 42.

24. Korsgaard, "Music Video Transformed," 517.

25. Stan Hawkins, "Introduction: Sensing Gender in Popular Music," in The Routledge Research Companion to Popular Music and Gender, ed. Stan Hawkins (London: Routledge, 2017), $8 . \Perp$ 26. Taylor, Sounds of Capitalism, 186. 
27. Nicholas Cook, "Music and Meaning in the Commercials," Popular Music 13, no. 1 (1994): $38 . \triangleq$ 28. “THE MEDIA BUSINESS; How MTV Has Rocked Television Commercials," The New York Times, October 9, 1989, accessed April 20, 2018, https://www.nytimes.com/1989/10/09/business/themedia-business-how-mtv-has-rocked-television-commercials.html. $\doteq$

29. Steven A. Seidman, "An Investigation of Sex-Role Stereotyping in Music Videos," Journal of Broadcasting \& Electronic Media 36, no. 2 (1992): 214-15.

30. Robin Thicke, “Robin Thicke - Blurred Lines ft. T.I. \& Pharrell (Unrated Version)," March 28, 2013, accessed April 25, 2020, https://www.youtube.com/watch?v=zwT6DZCQi9k..

31. Research into the gender performance of these artists and many other examples became prominent with the rise of 'new musicology' in the 1980s. Their influence has been widely acknowledged by scholars such as Sheila Whitely, Susan McClary, Simon Frith, Keith Negus and Angela McRobbie. $\triangleq$

32.

See Shaviro, Post-Cinematic Affect, 11-34;

Susan McClary, "Living to Tell: Madonna's Resurrection of the Fleshy," in Feminine Endings: Music, Gender, and Sexuality (Minneapolis: University of Minnesota Press, 1991), 148-66.

33. Carol Vernallis, Unruly Media: YouTube, Music Video, and the New Digital Cinema (Oxford: Oxford University Press, 2013), 220-1.

34. Lady Gaga, "Lady Gaga - Yoü And I (Official Music Video)," August 16, 2011, accessed April 29, 2020, https://www.youtube.com/watch?v=X9YMUOWeBwU..

35. Vernallis, Unruly Media, 220.

36. Carter, "Sex/Gender and the Media," 365-6.

37. Shaviro, Post-Cinematic Affect, 12-15.

38. Ibid., 12-13.

39. Sia, "Sia - Chandelier (Official Music Video)," May 6, 2014, accessed April 17, 2020, https://www.youtube.com/watch?v=2vj) PBrBU-TM.

40. Kai Arne Hansen, "Holding On For Dear Life: Gender, Celebrity Status, and Vulnerability-OnDisplay in Sia's 'Chandelier,'” in The Routledge Research Companion to Popular Music and Gender, ed. Stan Hawkins (London: Routledge, 2017), 89-92. 
41. Rhonda Richford, "Watch “The Nice Guys” Star Margaret Qualley Dance Her Way Through Spike Jonze's Kenzo Film," Hollywood Reporter, August 29, 2016, accessed August 7, 2020, https://www.hollywoodreporter.com/news/margaret-qualley-spike-jonzes-kenzoworld-923576.

42. Beautybox, "Perfume Kenzo World," August 4, 2017, accessed April 30, 2020, https://www.youtube.com/watch?v=176h17o3FEI.

43. For further analysis of professionals working across audiovisual media platforms, see Carol Vernallis, Holly Rogers and Lisa Perrott, eds., Transmedia Directors: Artistry, Industry and New Audiovisual Aesthetics (London: Bloomsbury, 2020).

44. PinkCoutureVids, "Maybelline "Dream Wonder" Liquid Foundation TV Commercial (Fall 2014)," August 6, 2014, accessed July 3, 2020, https://www.youtube.com/watch?v=061Sk000-tk..

45. Carol Vernallis, “The Kindest Cut: Functions and Meanings of Music Video Editing," Screen 42, no. 1 (2001): 21.

46. Skint Records, "Fatboy Slim - Weapon Of Choice [Official Video]," May 21, 2010, accessed April 26, 2020, https://www.youtube.com/watch?v=wCDIYvFmgW8

47. Mulvey, "Visual Pleasure," 19-20.

48. Ibid., $21 . \triangleq$

49. Vernallis, Experiencing Music Video, 34-5.

50. Gunter, "Gender Role Portrayals," 41. $\subseteq$

51. Vernallis, Unruly Media, 3.

52. Taylor Swift, “Taylor Swift - Delicate,” March 11, 2018, accessed April 5, 2020,

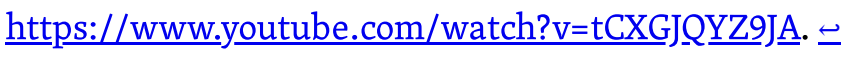

53. Sam Reed, “Taylor Swift's “Delicate” Video Looks a Lot Like Spike Jonze's Kenzo Perfume Ad," Hollywood Reporter, December 3, 2018, accessed April 5, 2020, https://www.hollywoodreporter.com/news/taylor-swifts-delicate-video-looks-a-lot-like-spikejonzes-kenzo-perfume-ad-1093880. $\doteq$

54. Shaviro, Post-Cinematic Affect, 10.

55. Wallis, "Performing Gender," $161 . \Leftarrow$ 